\title{
Chemical monitoring in the Dutch Wadden Sea by means of benthic invertebrates and fish*
}

\author{
Karel Essink \\ Ministry of Transport and Public Works, Rijkswaterstaat, Tidal Waters Division; \\ P. O. Box 207, 9750 AE Haren, The Netherlands
}

\begin{abstract}
In monitoring, it is of utmost importance to carefully define the purpose, the sampling strategy, as well as the analytical chemical and statistical requirements. Surveys are appropriate for describing the geographical variation in environmental contaminant levels. Repeated surveys and recurrent data collection at permanent locations provide means of detecting temporal trends. Results are presented here of surveys on pollution by trace metals, polychlorinated biphenyls and organochlorine pesticides in the Ems Estuary and Dutch Wadden Sea using Mytilus edulis, Mya arenaria, Arenicola marina, Nereis diversicolor and Crangon crangon as test organisms. Trends towards decreasing pollution by mercury are illustrated by monitoring data on Mytilus edulis and Zoarces viviparus. It is stressed that the results of chemical monitoring in organisms may be interpreted only in terms of the biological effects on the basis of relevant toxicological knowledge and/or additional bio-assays.
\end{abstract}

\section{INTRODUCTION}

In formulating a programme for chemical monitoring, it is essential to consider at least the questions Why?, What?, Where? and How? It should be made clear why monitoring is needed, or in other words which purpose(s) should be served by monitoring (cf. Meijers, 1986). A monitoring programme can be set up to check on set standards with respect to the degree of contamination of the ecosystem. The results will then show whether those standards are exceeded or not. If standard values are exceeded, authorities can take action. 'A monitoring programme can also serve the purpose of detecting trends, e.g. a decrease or increase of chosen parameters with time.

What is to be monitored has to be defined carefully, not only with respect to chemical compounds, but also with respect to the ecosystem compartment (water-dissolved, waterparticulate, sediment, organisms) in which the chemical compounds are to be monitored. If organisms are chosen, one or more species are to be selected relevant to the previously defined purposes of monitoring. Dependent on the organism(s) and chemical compound(s) selected, a decision has to be made whether the whole organism or only a specified organ or tissue is to be used for the chemical analysis.

Where monitoring is to be performed is of course largely determined by the purposes defined. Monitoring in order to check on set standards may be appropriate in known "hot spots". Monitoring for trends is meaningful in areas to which it can be foreseen that

* Presented at the VI International Wadden Sea Symposium (Biologische Anstalt Helgoland, Wattenmeerstation Sylt, D-2282 List, FRG, 1-4 November 1988) 
pollution will disperse, as well as in areas with valuable natural resources. Reference areas, i.e. areas with minimal pollution impact, should be included in a monitoring programme to increase the possibility of discriminating between naturally fluctuating and pollution-induced parameter values. These discriminations are essential to authorities responsible for the management of estuarine and coastal water bodies (cf. Beukema \& Essink, 1986).

The question of how monitoring is to be performed pertains to the sampling strategy (network of sampling stations, sampling frequency, sample size and number) (Cuff \& Coleman, 1979; Pearce \& Despres-Patanjo, 1988) and analytical methods, including a quality-assurance programme (Cofino, 1989). The entire set-up of the monitoring programme should enable a sound statistical treatment of the data. (Anonymous, 1982; Phillips \& Segar, 1986; Segar \& Stamman, 1986).

In this paper, data will be presented on surveys of contaminant concentrations (trace metals and organochlorines) in benthic invertebrates in the Ems Estuary, Dutch Wadden Sea and coastal waters of western Europe. Results of trend monitoring of mercury pollution in the Dutch Wadden Sea will be illustrated by data on the mussel Mytilus edulis and the viviparous blenny Zoarces viviparus.

\section{SURVEYS}

In 1984, a small-scale survey was carried out in the Ems Estuary (Essink et al., 1986). The purpose of this survey was to identify pollution sources of PCBs and some organochlorine pesticides. Three benthic invertebrates, the bivalve Mya arenaria and the polychaetes Arenicola marina and Nereis diversicolor were used. $M$. arenaria and $A$. marina were sampled at three locations; $N$. diversicolor was sampled at seven locations on the intertidal flats of the estuary.

Figure 1 shows that elevated concentrations of hexachlorobenzene (HCB) were found at location 4 , indicating a major source of $\mathrm{HCB}$ near Delfzijl. Similar results were obtained for the PCB congeners PCB-101, PCB-138, PCB-153, PCB-180 and, less clear, for PCB-28 and PCB-52 (Fig. 2), and hexachlorobutadiene (HCBu) (Essink et al., 1986). Near Delfzijl, industrial waste discharge was responsible for the observed distribution of pollution by $\mathrm{HCB}$ and $\mathrm{HCBu}$ in the Ems Estuary. As to the PCBs, there is no knowledge of discharge of PCB-containing wastewater. However, in Delfzijl fresh water is sluiced out from a large drainage area, which is supposed to contain PCBs. For the first four PCBcongeners mentioned, the concentrations in $N$. diversicolor are higher at locations 1 to 3 (outer part of the estuary) than at locations 5 to 7 (Fig. 2), indicating that for these contaminants the coastal waters of the North Sea are an additional source. Apparently, the congeners PCB-28 and PCB-52 have a much more diffuse origin.

Quite a different distribution pattern of concentrations was found for the pesticide $\gamma$ $\mathrm{HCH}$ (lindane) (Fig. 3). The higher concentrations found at location 1 are attributed to local discharges of surplus fresh water from Dutch agricultural areas as well as to the relatively high $\gamma-\mathrm{HCH}$ concentrations in coastal waters due to discharges by the rivers Weser and Elbe (Gaul \& Ziebarth, 1983).

Surveys extending over a larger area, viz. the Dutch Wadden Sea and Ems Estuary, have been carried out for organochlorines and trace metals (Duinker et al., 1983; Kramer et al., 1985). Figure 4 shows that for $\mathrm{HCB}$ and $\gamma-\mathrm{HCH}$ the Ems Estuary (locations 4 and 5) 

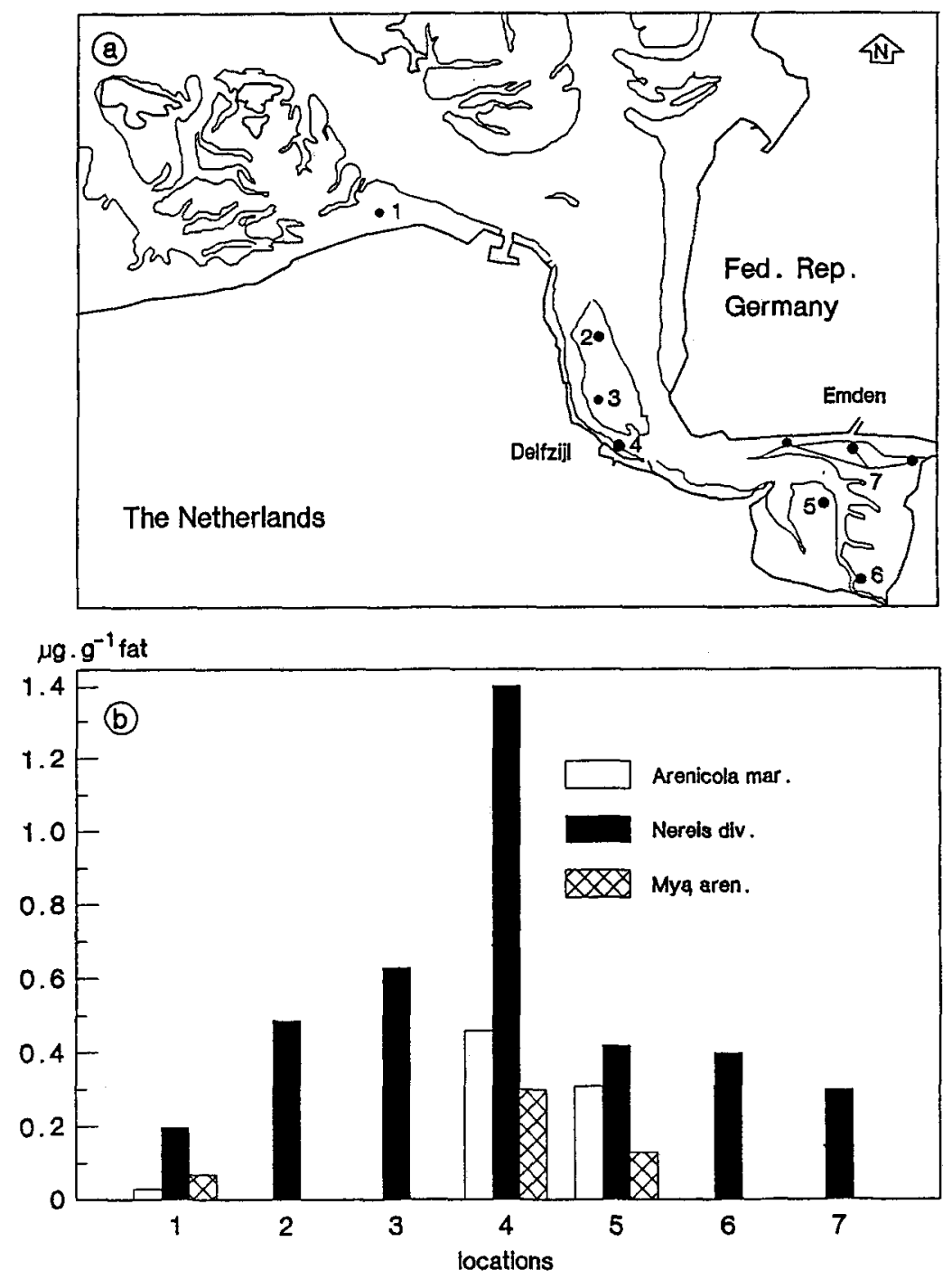

Fig. 1. Map of the Ems Estuary with sampling locations $(1-7)$ for intertidal benthic invertebrates (a) and concentrations of hexachlorobenzene (HCB) in pooled samples of Arenicola marina, Nereis diversicolor and Mya arenaria in 1984 (b)

and the westernmost part of the Wadden Sea (location 1) are more contaminated than the central part (locations 2 and 3). A similar contamination pattern was found for cadmium in 1982 (Fig. 5). So, in the area surveyed two contaminated subareas are present, indicating two important sources of pollution. This also holds for pollution by mercury as assessed by a survey of intertidal mussels Mytilus edulis in 1971-73 (De Kock \& Kuiper, 1981).

Large-scale surveys as carried out by De Wolf (1975) along the West European coasts between Arcachon (France) and Cape Skagen (Denmark), and between Land's End and 
$\mu g \cdot g^{-1}$ fat
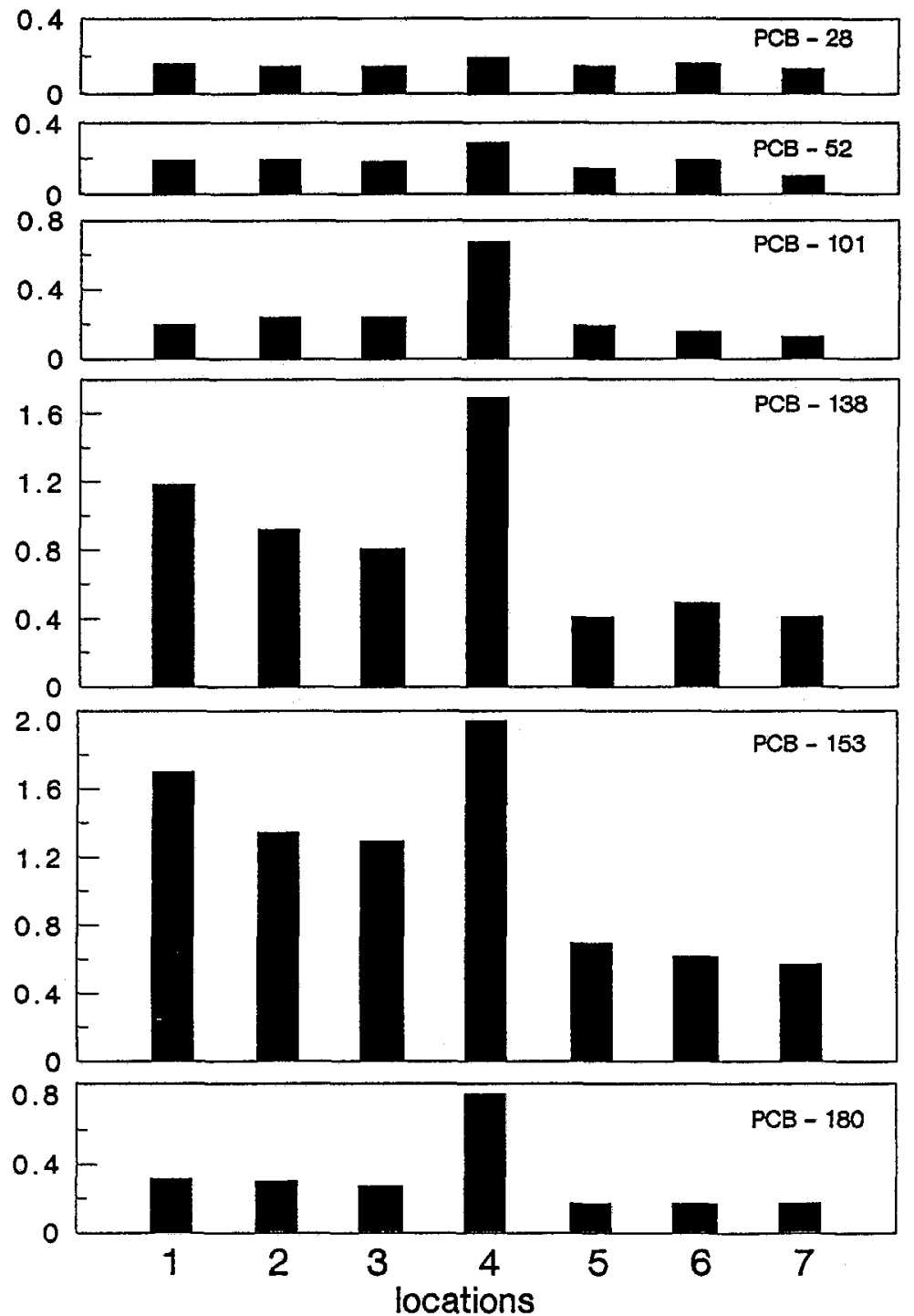

Fig. 2. Concentrations of 6 PCB congeners in pooled samples of Nereis diversicolor in the Ems Estuary in 1984. See Figure 1a for locations

Edinburgh (Great Britain) enable us to consider local pollution in a wider geographical and even international context. In 1971/72, mercury contents in intertidal mussels Mytilus edulis from the Ems Estuary were among the highest found in the entire survey. In September 1988, another large-scale survey was carried out by the Tidal Waters Division including the Danish, German and Dutch Wadden Sea as well as the remaining Dutch coastal zone as far as the Western Scheldt estuary. In this survey, samples were 


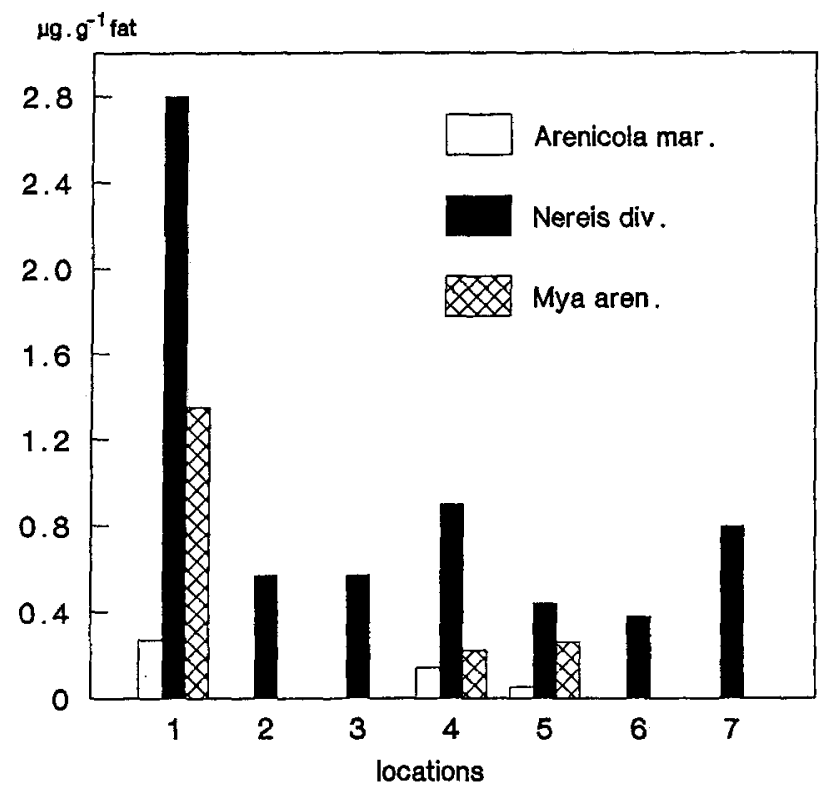

Fig. 3. Concentrations of $\gamma-\mathrm{HCH}$ in pooled samples of Arenicola marina, Nereis diversicolor and Mya arenaria in the Ems Estuary in 1984. See Figure 1a for locations

collected of Mytilus edulis, Arenicola marina and Macoma balthica which will be analysed for trace metals and organohalogens.

Carrying out surveys by collecting organisms from the field may be referred to as the "passive" method. The "active" method of exposing organisms at different locations for some time to ambient pollutant concentrations can also be used (see below). An example of this active method, applying Mytilus edulis to survey zinc contamination in Dutch coastal waters, is given by De Kock (1986).

\section{TREND MONITORING}

Repeated surveys, carried out in the Dutch Wadden Sea in 1982, 1985 and 1986, offer the possibility of detecting trends in trace metal concentrations of certain invertebrate species. In Figure 6, data are presented on concentrations of copper and cadmium in the species Arenicola marina and Crangon crangon. The concentrations are mean values of the concentrations found in three different length groups of animals. A trend for copper is not present at any of the locations sampled. For cadmium, however, a trend of decreasing concentrations is observed. The concentrations found in 1985 and 1986 are considerably lower than in 1982 at most of the locations. The higher concentrations observed at location 8 in 1986 as compared with 1985 are not statistically significant. The decrease of cadmium contamination in the western part of the Dutch Wadden Sea can be explained by the strong reduction of the discharges via the river Rhine: from ca 100 tonnes.yr $^{-1}$ in $1980 / 81$ to ca 10 tonnes. $\mathrm{yr}^{-1}$ in 1984/85 (Folkertsma, 1987). No data are available on cadmium discharges in the Ems Estuary. 

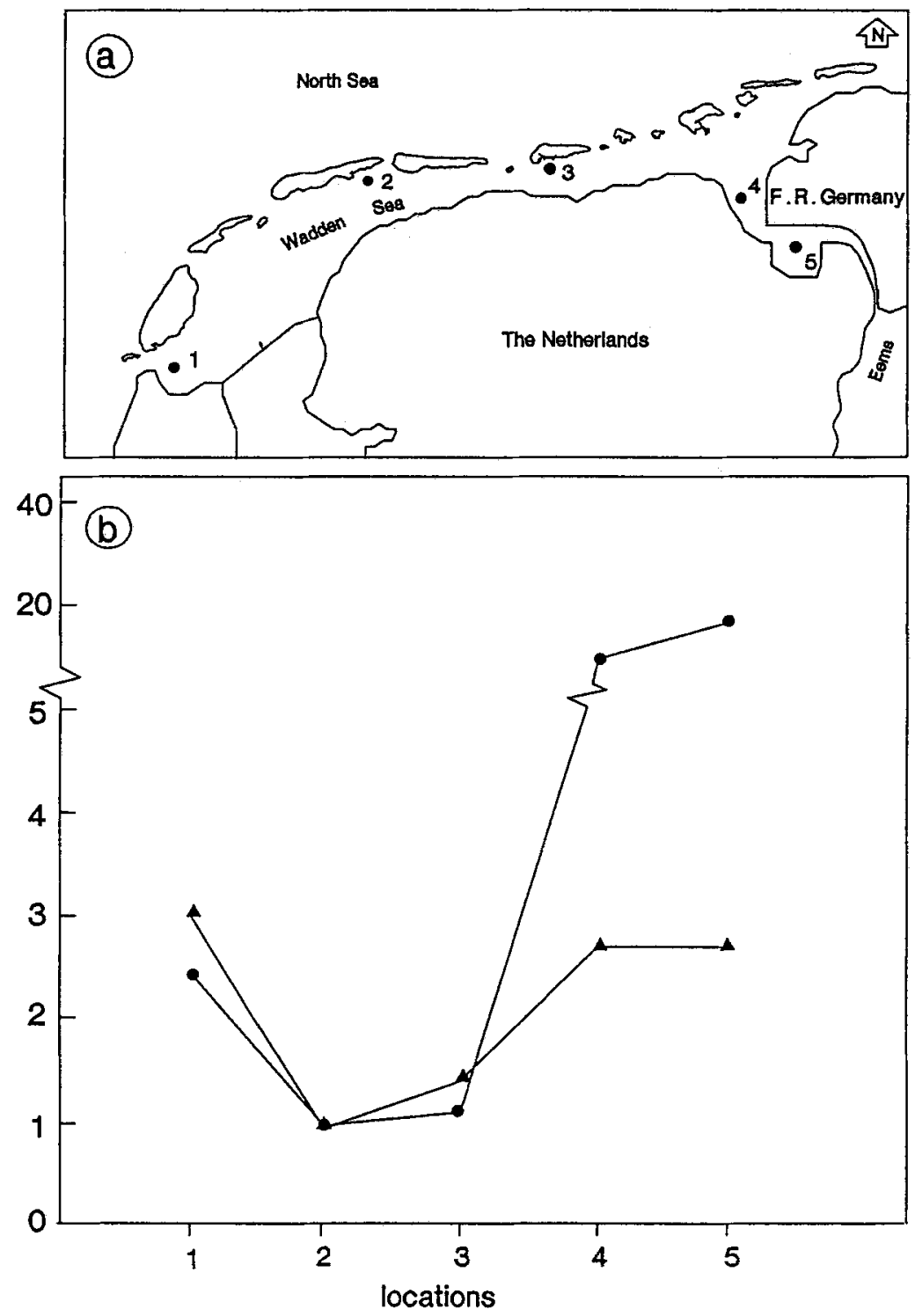

Fig. 4. Map of the Dutch Wadden Sea and Ems Estuary (a) and relative concentrations of HCB (•) and $\gamma-\mathrm{HCH}(\Delta)$ in Arenicola marina at five locations in 1979 (b). Concentrations found at location 2 are set at 1. (After Duinker et al., 1983)

Figure 7 shows the results of trend monitoring for mercury pollution in the Ems Estuary using Mytilus edulis (Pries et al., 1984). For this monitoring programme two different methods were used. At first, "passive" monitoring was applied, using mussels from local populations. Later, the "active" method was used, in which mussels from a relatively unpolluted reference location were transplanted to the monitor locations and 

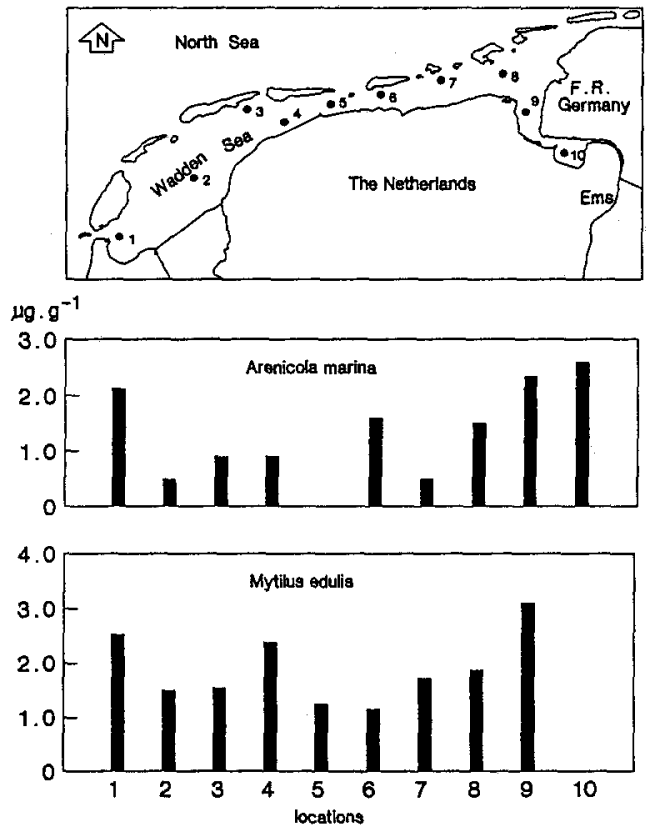

Fig. 5. Cadmium concentrations in Arenicola marina (pooled samples of specimens weighing 3-5 g) and Mytilus edulis (mean of pooled samples of 3-4, and 5-6 cm shell length) at 10 locations in the Dutch Wadden Sea and Ems Estuary in 1982. (After Kramer et al., 1985)

exposed for some time (cf. De Kock \& Kuiper, 1981; De Kock, 1983). The strong decrease of mercury concentrations in mussels coincides with a decrease of Dutch mercury discharges into the estuary (cf. Essink, 1988), which indicates the positive effect of the government-imposed pollution abatement scheme.

Similar results have been obtained in a monitoring programme using viviparous blenny (Zoarces viviparus), a non-migratory teleostean fish (Essink, 1980, 1985, 1988). A significant decrease in contamination could be demonstrated for the western Dutch Wadden Sea as well as for the Ems Estuary (Fig. 8), following an effective reduction of the major mercury discharges into Dutch coastal waters (cf. Essink, 1988). In Figure 8, a baseline level of $70 \mu \mathrm{g} . \mathrm{kg}^{-1}$ wet weight is presented derived from Scottish data (Essink, 1985, 1988).

\section{DISCUSSION}

Monitoring of contaminants in the biotic compartment of the ecosystem, e.g. the water column, as compared to the abiotic compartment, has some advantages. Contaminant concentrations in an organism are usually well above the detection limit of analytical methods. Furthermore, these concentrations represent an integration of temporal variations in the occurrence of the contaminants in the aquatic environment. An essential prerequisite, however, for applying biota in monitoring programmes is a stationary mode of life of the species concerned. This prerequisite restricts meaningful chemical monitoring in biota to sedentary organisms, such as fucoids and macrobenthic 

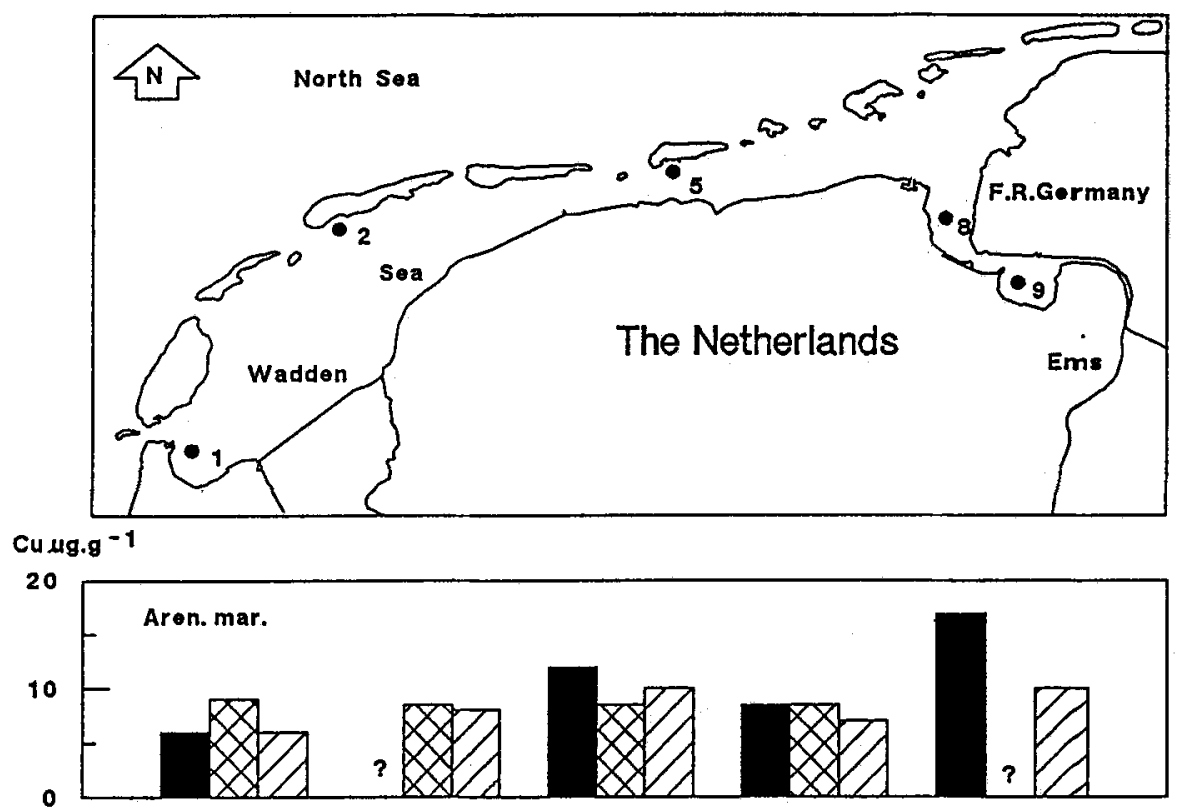

Cu ug.g -1

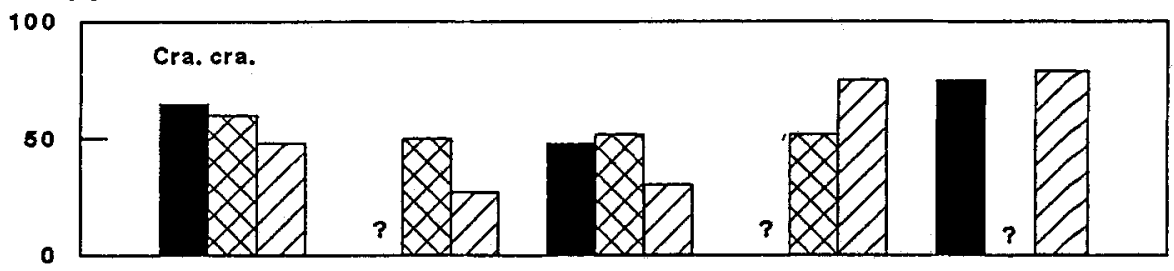

\section{Cd ug.g ${ }^{-1}$}

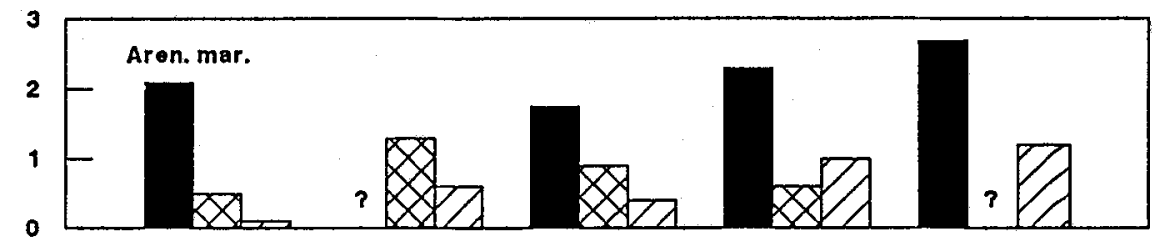

Cd ug.g-1

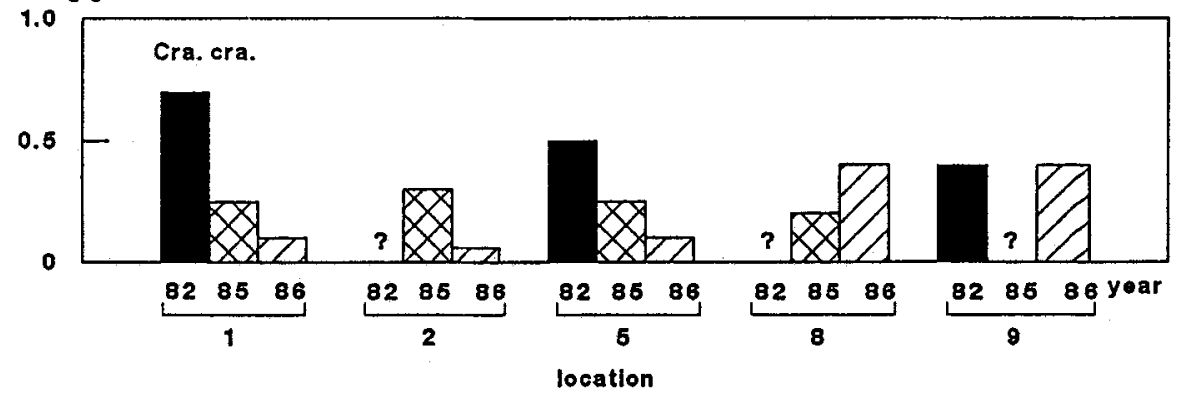




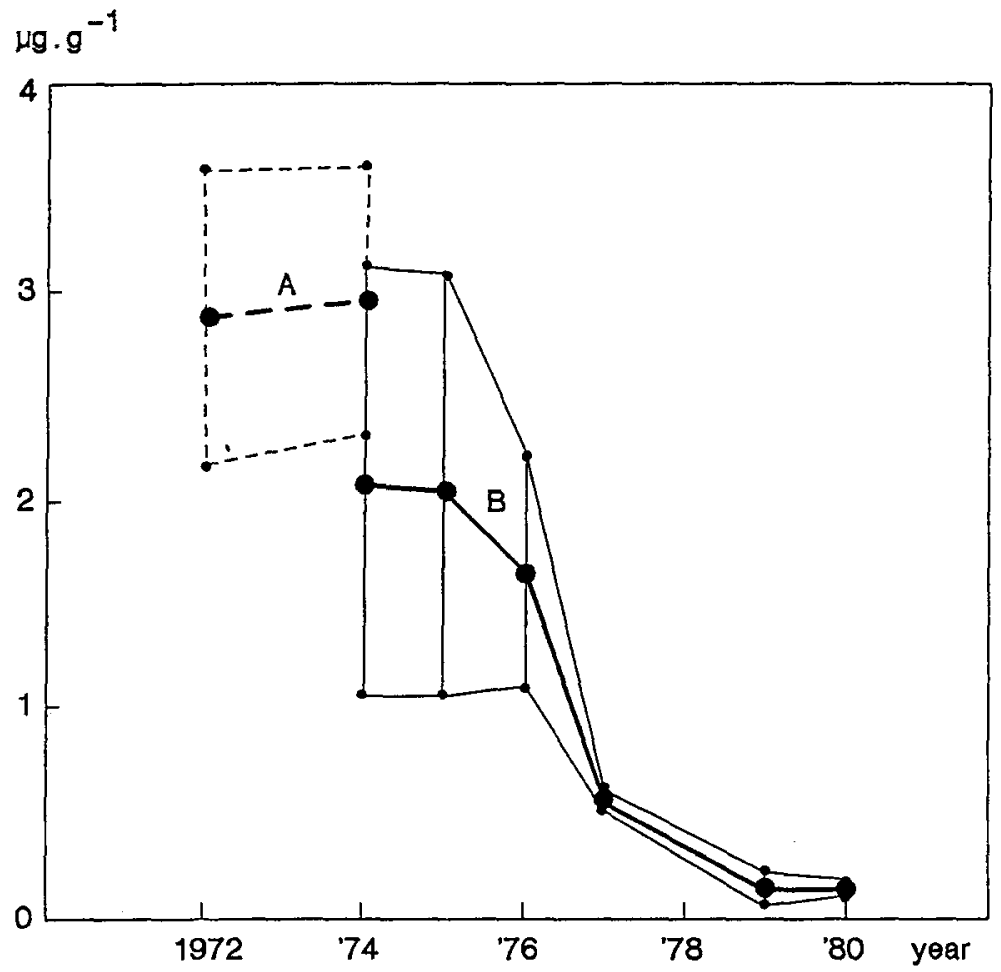

Fig. 7. Decrease of mercury concentrations in Mytilus edulis in the Ems Estuary. A: mean and range of local intertidal population. B: mean and range of transplanted mussels. (After Pries et al., 1984)

infauna, or to stationary species such as Zoarces viviparus. The use of eggs of shorebreeding bird species also meets this prerequisite as is shown by Becker (1989).

Chemical monitoring in organisms cannot be considered equal to biological effects monitoring; both types of monitoring are rather complementary. Chemical monitoring in organisms does provide information on the accumulation of contaminants in these organisms. This information may be interpreted in terms of biological effects. However, such an interpretation can be based only on sound knowledge of the kinetics and toxicology of the contaminants and species concerned (cf. Adema et al., 1972; Boon, 1985; Boon \& Duinker, 1986; Everaarts, 1986; Reijnders, 1986; De Wolf et al., 1972).

Concentrations of contaminants in intertidal invertebrates, although being sampled at the same location, may vary largely between species (Figs 1, 3,5 and 6). This implies that a species which is quite appropriate for monitoring certain contaminant compounds will not necessarily be appropriate for other pollutants. So the proper choice of species in a chemical monitoring programme is highly dependent on the purpose set with respect to the range of contaminants to be monitored (cf. Zauke et al., 1987, 1988).

Fig. 6. Concentrations of copper and cadmium in Arenicola marina (Aren. mar.) and Crangon crangon (Cra. cra.) at 5 locations in the Dutch Wadden Sea and Ems Estuary in 1982, 1985 and 1986.

(From J. M. Everaarts, unpubl.) 

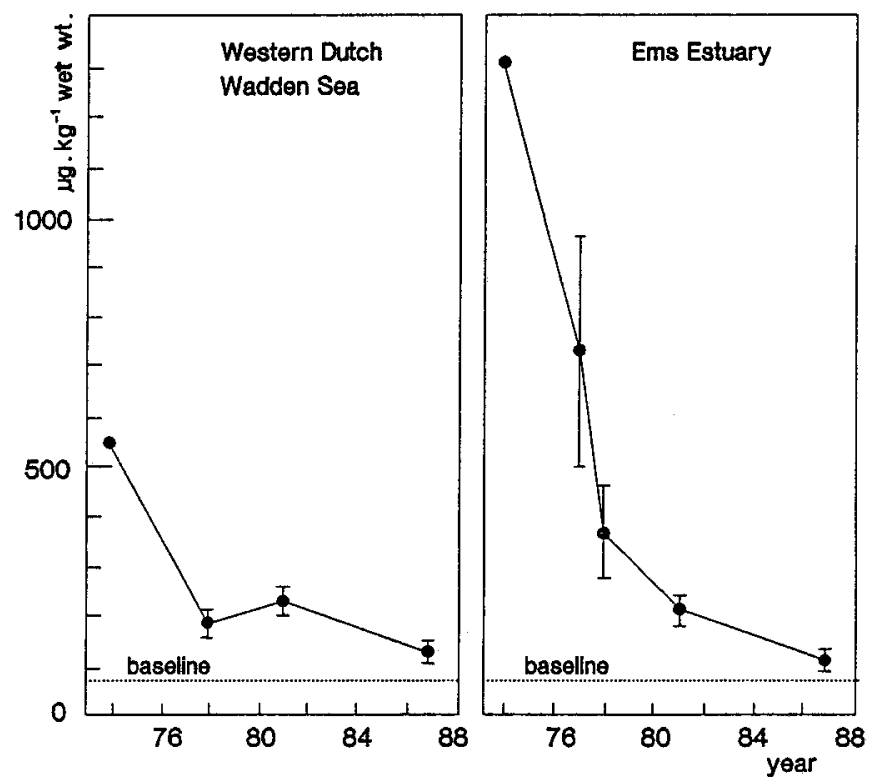

Fig. 8. Decrease of mercury concentrations in $180 \mathrm{~mm}$ Zoarces viviparus from western Dutch Wadden Sea and Ems Estuary. Concentrations and $95 \%$ confidence intervals estimated from regressions of mercury concentration on length. (After Essink, 1980, 1985, 1988). Baseline level founded on data from Scotland (see text)

Monitoring of local populations is not always possible because of the (temporary) absence of the species that has to be monitored. "Active" monitoring may be applied to overcome this problem. There is, however, at least one drawback to be mentioned. What happens when, in an active monitoring programme, Mytilus edulis is transplanted to a location where growth conditions are very poor, e.g. the Dollard (cf. Essink \& Bos, 1985)? Will the accumulation process of the contaminants be similar to that under good growth conditions? How must we interpret the concentrations determined at the end of the exposition period? An experimental approach is needed to elucidate these problems.

In estuaries where the distribution pattern of most species is strongly determined by the salinity gradient, there is the problem of species selection for monitoring. Only euryhaline species, such as Nereis diversicolor, can be used to monitor locations distributed over the far greater part of the salinity range in estuaries (Essink et al., 1986). According to Pries et al. (1984), the mussel Mytilus edulis can be used well in the salinity range $15-35 \% \mathrm{~S}$.

As mentioned above, monitoring of pollutant concentrations in organisms does not provide direct information on the pollution effects in the organisms concerned. When authorities responsible for the management of estuaries and coastal waters, as well as scientists observing elevated contaminant levels in organisms, want to learn what the effects are, additional experiments (bioassays; Meijers, 1986) are necessary. To investigate the effect of elevated mercury contents in the Ems Estuary as compared with the western Dutch Wadden Sea in 1974-78, the survival of fry of Zoarces viviparus was used as parameter in a laboratory bio-assay. Although the mercury contents in $Z$. viviparus 
from Ems Estuary and western Dutch Wadden Sea no longer differed significantly in 1981 (Fig. 8), a significant difference in fry survival was found. The mean number of days after which $50 \%$ of the fry of a female was still alive (survival time: $\mathrm{ST}_{50}$ ) was greater in fry born of females from the western Dutch Wadden Sea (Table 1). Survival was better in the area that had experienced lesser mercury pollution. In Sweden, fry of eelpout have been succesfully used in bio-assay studies by Jacobsson et al. (1986).

Table 1. Survival (ST50; days) of fry of Zoarces viviparus

\begin{tabular}{|lllll|}
\hline Location & $\mathrm{n}$ & $\mathrm{ST}_{50}$ & s.d. & $\mathrm{p}$ \\
\hline Western Wadden Sea & 18 & 55.6 & 3.3 & \\
Ems Estuary & 18 & 50.7 & 7.1 & 0.01 \\
\hline
\end{tabular}

Acknowledgements. Thanks are due to Dr. J.M. Everaarts (Texel) for permission to use his unpublished data on trace metals in intertidal invertebrate species. R. Jungcurt prepared the figures.

\section{LITERATURE CITED}

Adema, D. M. M., Swaaf-Mooy, S. I. de \& Bais, P., 1972. Laboratory investigations concerning the influence of copper on mussels (Mytilus edulis). - TNO-Nieuws 27, 482-487.

Anonymous, 1982. Guidelines to be followed for sample collection, preparation and analysis of fish and shellfish in the conduct of cooperative monitoring. - Coop. Res. Rep. 117, Appendix.

Becker, P. H., 1989. Seabirds as monitor organisms of contaminants along the German North Sea coast - Helgoländer Meeresunters. 43, 395-403.

Beukema, J. J. \& Essink, K., 1986. Common pattern in the fluctuations of macrozoobenthic species living at different places on tidal flats in the Wadden Sea. - Hydrobiologia 142, 199-207.

Boon, J. P., 1985. Uptake, distribution, and elimination of selected PCB components of Clophen A40 in juvenile sole (Solea solea) and effects on growth. In: Marine biology of polar regions and effects of stress on marine organisms. Ed. by J. S. Gray \& M. E. Christiansen. Wiley, Chichester 493-512.

Boon, J. P. \& Duinker, J. C., 1986. Monitoring of cyclic organochlorines in the marine environment. Environ. Monit. Assess. 7, 189-208.

Cofino, W. P., 1989. Methodology of chemical monitoring in the marine environment. - Helgoländer Meeresunters. 43, 295-308.

Cuff, W. \& Coleman, N., 1979. Optimal survey design: lessons from a stratified random sample of macrobenthos. - J. Fish. Res. Bd Can. 36, 351-361.

Duinker, J. C., Hillebrand, M. T. J. \& Boon, J. P., 1983. Organochlorines in benthic invertebrates and sediments from the Dutch Wadden Sea; identification of individual PCB components. - Neth. J. Sea Res. 17, 19-38.

Essink, K., 1980. Mercury pollution in the Ems estuary. - Helgoländer Meeresunters. 33, 111-121.

Essink, K., 1985. Monitoring of mercury pollution in Dutch coastal waters by means of the teleostean fish Zoarces viviparus. - Neth. J. Sea Res. 19, 177-182.

Essink, K., 1988. Decreasing mercury pollution in the Dutch Wadden Sea and Ems Estuary. - Mar. Pollut. Bull. 19, 317-319.

Essink, K. \& Bos, A. H., 1985. Growth of three bivalve molluscs transplanted along the axis of the Ems Estuary. - Neth. J. Sea Res. 19, 45-51.

Essink, K., Jagtman, E. \& Ritsema, R., 1986. Usefulness of sediment and three benthic invertebrates as indicators of organochlorine pollution in an estuarine environment. - Rep. Rijkswaterstaat, Tidal Wat. Div. Groningen GWAO-86.157, 1-17. 
Everaarts, J. M., 1986. Is monitoring of respiratory properties of the haemoglobin of the lugworm Arenicola marina meaningful? - Environ. Monit. Assess. 7, 273-283.

Folkertsma, F., 1987. Review of programmes and measures for cadmium in The Netherlands. - Note. Rijkswaterstaat, Institute for Inland Water Management and Waste Water Treatment, Lelystad 87.106X, 1-23.

Gaul, H. \& Ziebarth, U., 1983. Method for the analysis of lipophilic compounds in water and results about the distribution of different organochlorine compounds in the North Sea. - Dt. hydrogr. $Z$. $36,191-212$.

Jacobsson, A., Neuman, E. \& Thoreson, G., 1986. The viviparous blenny as an indicator of environmental effects of harmful substances. - Ambio 15, 236-238.

Kock, W. C. de, 1983. Accumulation of cadmium and polychlorinated biphenyls by Mytilus edulis L., transplanted from pristine water into pollution gradients. - Can. J. Fish. aquat. Sci. 40 (Suppl. 2), 282-294.

Kock, W. C. de, 1986. Monitoring bio-available marine contaminants with mussels (Mytilus edulis L.) in the Netherlands. - Environ. Monit. Assess. 7, 209-220.

Kock, W. C. de \& Kuiper, J., 1981. Possibilities for marine pollution research at the ecosystem level:Chemosphere 10,575-603.

Kramer, C. J. M., Boon, J. P., Duinker, J. C., Everaarts, J. M., Hillebrand, M. T. J., Nolting, R. F. \& Vlies, E. M. van der, 1985. Contaminanten in de Waddenzee en een vergelijking met de omliggende gebieden. Nederlands Instituut voor Onderzoek der Zee, Texel, $120 \mathrm{pp}$.

Meijers, E. M. J., 1986. Defining confusions - confusing definitions. - Environ. Monit. Assess. 7, 157-159.

Pearce, J. B. \& Despres-Patanjo, L., 1988. A review of monitoring strategies and assessments of estuarine pollution. - Aquat. Toxic. 11, 323-343.

Phillips, D. J. H. \& Segar, D. A., 1986. Use of bio-indicators in monitoring conservative contaminants: programme design imperatives. - Mar. Pollut. Bull. 17, 10-17.

Pries, C., Kock, W. C. de \& Marquenie, J. M. 1984. Specimen banks and the monitoring of surface water pollution by aquatic organisms. In: Environmental specimen banking and monitoring as related to banking Ed. by R. A. Lewis, N. Stein \& C. W. Lewis. Nijhoff, Boston, 88-94.

Reijnders, P. J. H., 1986. Reproductive failure in common seals feeding on fish from polluted coastal waters. - Nature, Lond., 324, 456-457.

Segar, D. A. \& Stamman, E., 1986. Fundamentals of marine pollution monitoring programme design. - Mar. Pollut. Bull. 17, 194-200.

Wolf, P. de, 1975. Mercury content of mussels from West European coasts. - Mar. Pollut. Bull. 6, 61-63.

Wolf, P. de, Kock, W. C. de \& Stam, A., 1972. Field experiments on the influence of copper and mercury in a natural mussel bed. - TNO-Nieuws 27, 497-504.

Zauke, G.-P., Meurs, H.-G., Todeskino, D., Kunze, S., Bäumer, H.-P. \& Butte, W., 1987. Untersuchungen zur Verwendung von Bioindikatoren für die Umweltüberwachung im Ästuarbereich der Elbe, Weser und Ems. Teil 3. Zum Monitoring von Cadmium, Blei, Nickel, Kupfer und Zink in Balaniden (Cirripedia: Crustacea), Gammariden (Amphipoda: Crustacea) und Enteromorpha (Ulvales: Chlorophyta). - ForschBer. FKZ Wasser 10205 209, 1-144.

Zauke, G.-P., Meurs, H.-G., Schrey, K. \& Bäumer, H.-P., 1988. Influence of species, life-history status, and sampling techniques on $\mathrm{Cd}, \mathrm{Pb}, \mathrm{Ni}, \mathrm{Cu}$, and $\mathrm{Zn}$ in estuarine gammarids. - Crustaceana (Suppl.) 13, 283-285. 